$P-693$ 中国における女性尿道症候群患者の睦朕組樈所見

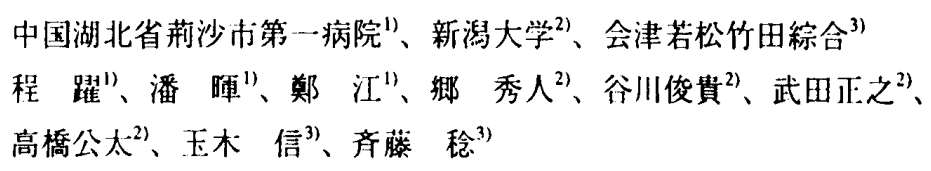

【日的】女性尿道症俟群とは、膀胱刺激症状を主訴とし、膿尿・細菌尿を伴わないものと定義されてい る（Stevens, 1923）が、中国人女性の膀胱組織像に関する報告は少ない。今回、中国における女性尿道 症候群の膀胱組織像について検討したので報告する。

【対象・方法】1990年10月より1995年 4月までに中国湖北省荆沙市第一病院泌尿器科を受診した女性尿 道症候群患者のうち58例を対象とした。年秢は18才から63才であり、30才台と40才台にビークを認めた。 これらの患者に对して内梘鏡下に膀胱粘膜生検術を行い、通常のH\&E染色による病理組織学的検討を行つ た。

【結果】全例で病理組織学的に異常所見が認められ、この病理所見は次の 6 種類に大別された。1)橉漫 性炎症；これはすべての患者に認められた。2)扁平上皮化成；4例（6.9\%）に見られた。3)腺性毫胞性 膀腅炎；9例( $15.52 \%) に$ 見られた。Brunn's nestを伴っていた。 4)乳頭様增殖；4例（6.9\%）に見られ た。5)ボリープ様增殖；2例（3.45\%）に見られた。6)腸粘膜样化生；1例（1.72\%）に見られた。

【結論および考察】女性尿道症候群患者の膀脱粘膜には少なくとも涂漫性炎症を伴う病理学的变化を認

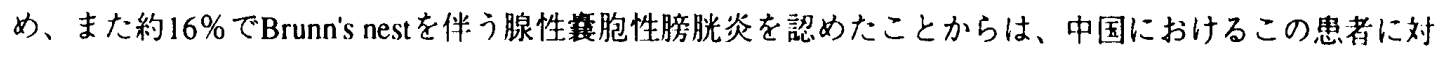
する膀胱粘膜病理検相の必要性を認めざるを得ない。この慢性炎症の原因については諎説があるが、今 後の検討を要する。

\title{
$P-694$ 先天的路形成不全マウスの解析
}

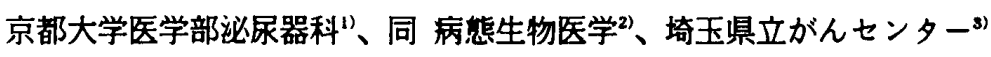

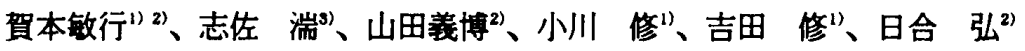

ヒトにおける先天的骨形成不全は、両側骨を欠損するPotter 症候群をはじめ、数多くの報告例がある。 その頻度はおよそ 1000 人に 1 人と先天異常の中では比較的高いが、その発生機構はほとんど解明されて いない。我々のもつddYマウスから近交系化されたDDS/Kマウスは、約 $60 \%$ の個体に片側あるいは両 側の督欠損をみる先天的督形成不全モデルマウスである。

[目的・方法] DDS/Kマウスの督形成不全の病態ならびにその责任逞伝子を、健常骨(両骨)マウス(NFS 系、A/J/Kyo系)との交配実駼ならびにマイクロサテライト法を用いた連鎖解析により解明する。

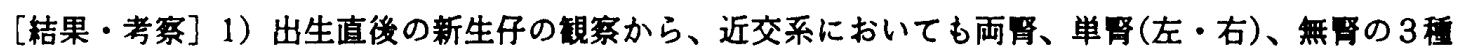
類の表現型をとり、両骨: 単骨: 無骨の類度は約 $4: 5: 1$ であった。2）約250個体F1世代の钼察から は督形成不全はみられなかった。3）DDS/Kへの退交配世代では約 $15 \%$ 骨の形成不全をみた。4）、 イクロサテライト法を用いた連镍解析の結果、NFS系との交眍では费任道伝子のうち一つがマゥス染色 体2番にマッピングされた。以上の結果から、この形觉は常染色体劣性の䢖伝様式をとり、複数の道伝子

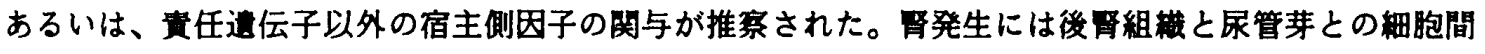
相互作用が必要である。今回、胎生期における骨形成の钼察結果もあわせて報告する予定である。 